\title{
J. Michael Waldram Memorial Model Forest Fellowship
}

n 2006, the Canadian Model Forest Network announced the establishment of the J. Michael Waldram Memorial Model Forest Fellowship, to be offered as part of the suite of awards bestowed annually by the Institute. The Fellowship is open to all Canadian Aboriginal youth enrolled in at least their second year in a natural resource management program at a Canadian University or College.

This year's recipient is Kristin Smart of Vancouver. Kristen is currently a student of the University of British Columbia’s Forest Resource Management Program. At the end of her second year at $\mathrm{UBC}$, a desire to learn more about Aboriginal communities in British Columbia and Aboriginal Forestry compelled her to switch to the Forest Resource Management. For the past three summers, Kristin has worked as a dispatcher and Dispatch Lead for BC Wildfire Service. Looking to the future, she hopes to use the skills she has developed in communications and knowledge gained in resource management, to help find solutions to improve social relations, build trust and help foster successful land management arrangements between Indigenous nations and the provincial government of $\mathrm{BC}$, in the Forestry Sector. I am very pleased to present Kristin Smart with the 2016 J. Michael Waldram Memorial Model Forest Fellowship.

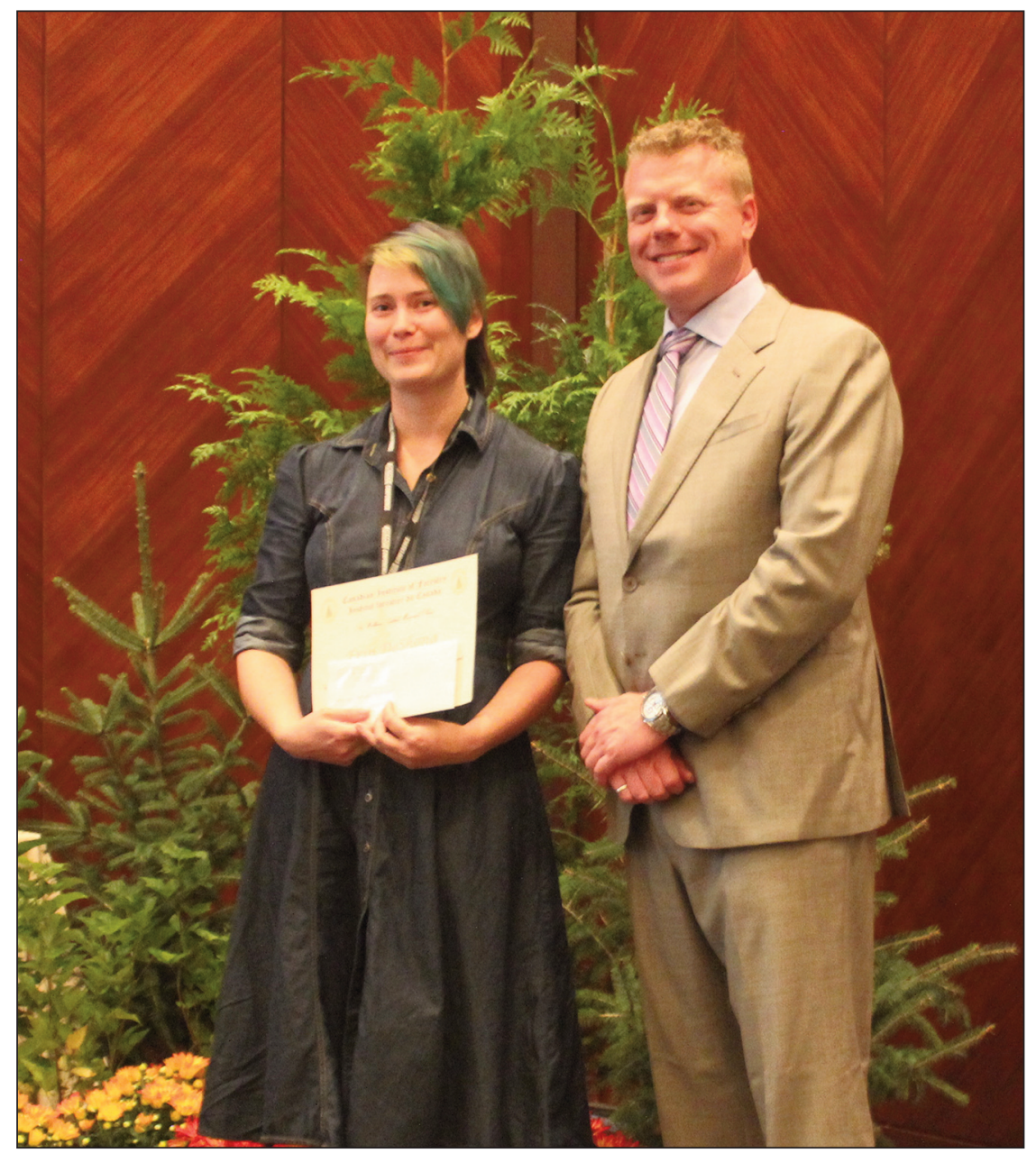

Kristin Smart with CIF/IFC President Jonathan Lok. 


\section{Gaining a perspective on world forestry}

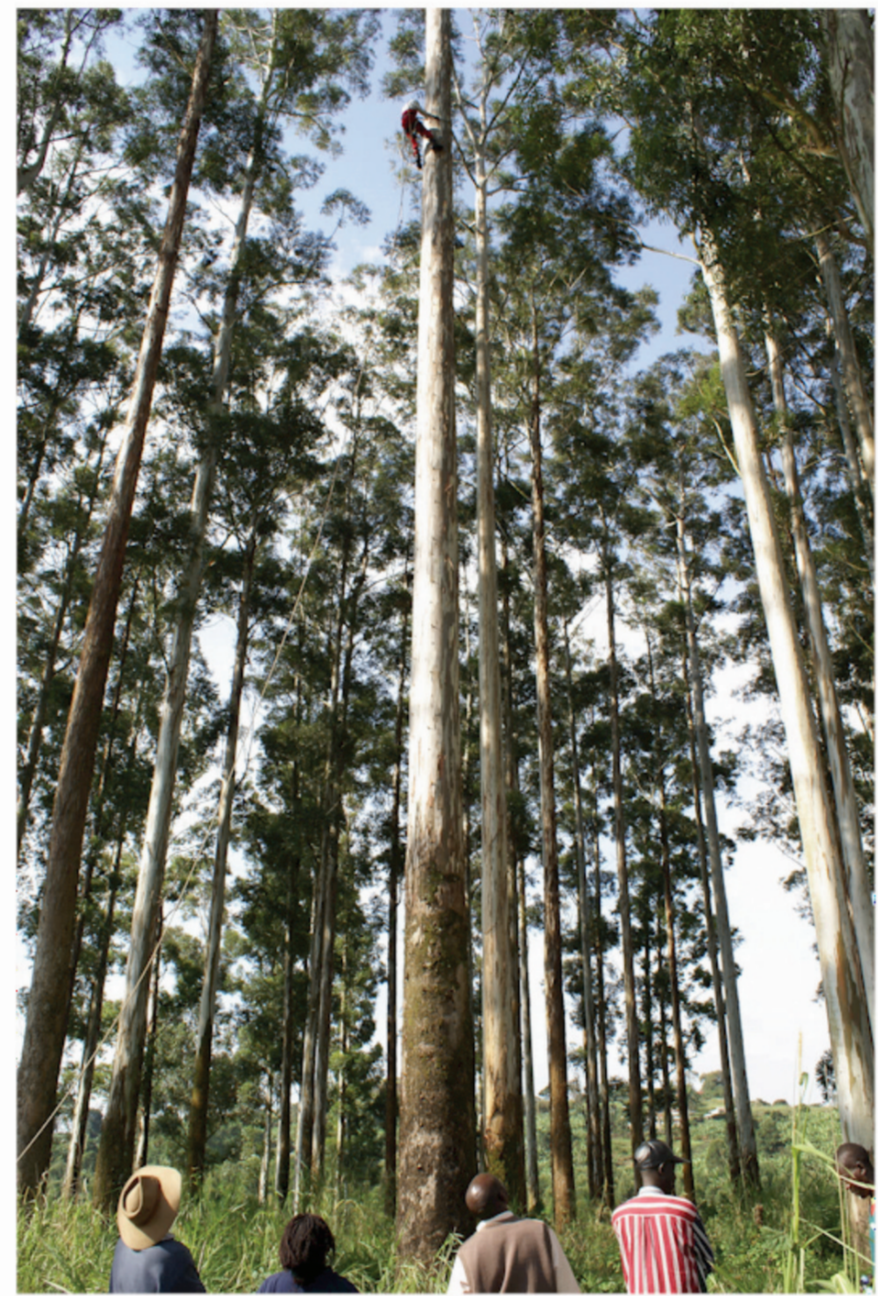

The Commonwealth Forestry

Association is the world's leading professional forestry association

focused on international forestry. We:

- Publish world-class science in our peer-reviewed forestry journal, the International Forestry Review.

- Facilitate networking of professional members and organisations and exchange of knowledge via our quarterly newsletter, website, Facebook page and Twitter feed.

- Encourage professional excellence and promote career development using a range of awards, such as the Queen's Award for Forestry, the Young Forester Award and the Young Scientist Research Award.

- Carry out a range of specific projects in the field that have been identified by our membership.

- Promote capacity building by helping to organise training courses, workshops, and conferences.

We are also the home to the secretariat for the Standing Committee on Commonwealth Forests, which is comprised of representatives of all of the forest departments from throughout the Commonwealth. The committee provides a unified voice on forestry matters to governments and international meetings and organises the Commonwealth Forestry Conference, an event which takes place every four years.

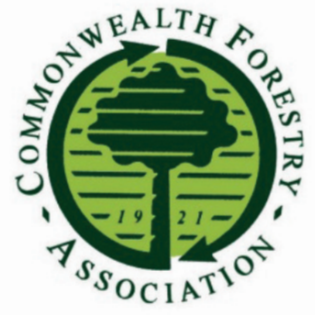

If you join us you'll be supporting future generations of foresters who work on our behalf to manage the environment of trees and forests. Membership is open to all including citizens of non-Commonwealth countries and Commonwealth countries.

Find out more at www.cfa-international.org 


\section{Associate Ediltors/Rorédacteurs}

\section{Dr. Paul L. Aird}

Emeritus Professor,

Forest Conservation Policy,

University of Toronto

\section{Dr. Ken Baldwin}

Forest Ecology Researcher,

Great Lakes Forestry Centre,

Natural Resources Canada

\section{Prof. Martin Beland}

Professeur de sylviculture et ecologie foresterie, Universite de Moncton, Campus d'Edmunston

\section{Dr. Ryan Bullock}

Asst. Professor,

Environmental Studies and Sciences and Centre for Forest Interdisciplinary Research,

University of Winnipeg

Dr. James M. Buttle

Professor of Geography, Trent University

\section{Dr. Jiaxin Chen}

Mitigation and Adaptation Research Scientist, Ontario Forest Research Institute, Ministry of Natural Resources and Forestry

\section{Dr. Verena C. Griess}

Asst. Professor of Forest Management, Faculty of Forestry, University of British Columbia

\section{Dr. Ron Hall}

Remote Sensing Inventory Specialist, Northern Forestry Centre,

Natural Resources Canada

\section{Dr. Andrew Kenney}

Emeritus Professor, Urban Forestry, Agroforestry and Tropical Forestry, University of Toronto
Dr. Maureen Kershaw

Science Coordinator,

Science and Research Branch,

Ontario Ministry of Natural

Resources and Forestry, Sault Ste.

Marie

\section{Dr. Anil R. Kizha}

Asst. Professor of Forest Operations, School of Forest Resources,

University of Maine

\section{Dr. Van Lantz}

Dean, Faculty of Forestry and Environmental Management, University of New Brunswick

\section{Dr. Valerie LeMay}

Professor of Forest Biometrics and Measurements, Dept. of Forest Resources Management, University of British Columbia

\section{Professor Martin Luckert}

Resource Economics and Environmental Sociology,

University of Alberta

\section{Dr. Rongzhu Man}

Research Scientist, Ontario Forest Research Institute, Ontario Ministry of Natural Resources and Forestry

\section{Dr. Peter Marshall}

Professor and Associate Dean, Faculty of Forestry,

University of British Columbia

\section{Professor David L. Martell}

Fire and Forest Management Systems, Faculty of Forestry, University of Toronto

\section{Dr. Keith M. McClain}

National Pine Beetle Ecology

Program Leader,

Foothills Research Institute

\section{Dr. Rory L. Mclntosh}

Provincial Forest Entomologist and Pathologist, Forest Service Branch, Ministry of Environment, Prince Albert, Saskatchewan

\section{Dr. Margaret Penner}

Forest Analysis Ltd., Huntsville, Ontario

Jim Richardson

Poplar and Willow Council of Canada

Ms. Ngaire Roubal

Forest Policy Analyst, Ontario Ministry of Natural Resources and Forestry

Professor Jean-Claude Ruel

Professeur titulaire et directeur du départment des sciences du bois et de la forêt, Université Laval

\section{Dr. Michael Stoehr}

A/Manager, Forest Genetics, Forests, Lands and Natural Resource Operations, Government of British Columbia

\section{Dr. Gordon F. Weetman}

Professor Emeritus, Forest and Conservation Sciences Department, University of British Columbia

\section{Dr. Adam Wellstead}

Assistant Professor, Department of Environmental and Energy Policy, Michigan Technological University

\section{Dr. Stephen Wyatt}

Professeur adjoin en aspects sociaux et politques de la foresterie, Faculté de foresterie, Université de Moncton 